\title{
Ekowisata dan Wisata Religius sebagai Relasi antara Manusia, Alam dan Tuhan
}

\author{
Syihabul Furqon', Busro Busro², Abdul Syukur ${ }^{3}$ \\ UIN Sunan Gunung Djati Bandung, Indonesia ${ }^{1,2,3}$ \\ Email: syihabul.f@uinsgd.ac.id
}

\begin{abstract}
The development of the world of tourism so rapidly from year to year. This implies an inevitable new tourist attraction. This development has its traces from the 20th century as a result of the decline of human existence, the objectification of nature and the breaking of the chain of sacredness with God through tradition. The second decade of the 21st century shows that this disconnection and decadence can be rewoven through tourism. This research will explore the statement: what kind of tourism model can then intertwine humans' disconnection from themselves, nature and God? The result is that in the ecotourism and religious tourism models there is a possibility of a harmonious mutualism symbiosis. Specifically in this study, the authors found that ecotourism (Trigonasantri Garden) and religious tourism objects (Petilasan Linggabuana) have a fundamental component—-traditionally—relationship between humans, nature and God.
\end{abstract}

Keywords: tourism, ecotourism, religious tourism, traditionalism.

\begin{abstract}
Abstrak
Perkembangan dunia pariwisata demikian pesat dari tahun ke tahun. Ini mengimplikasikan objek wisata baru yang tidak terhindarkan. Perkembangan ini memiliki jejaknya dari abad 20 sebagai akibat dari kemerosotan eksistensi manusia, objektivasi alam dan putusnya mata rantai sakralitas dengan Tuhan melalui tradisi. Dekade kedua abad 21 menunjukkan bahwa keterputusan dan dekadensi ini dapat dijalin ulang melalui kegiatan wisata. Penelitian ini akan menelusuri pernyataan: model wisata seperti apa yang kemudian dapat menjalin keterputusan manusia dari dirinya, alam dan Tuhan? Hasilnya adalah bahwa dalam model ekowisata dan wisata religius terdapat kemungkinan simbiosis mutualisme yang harmonis. Khusus dalam penelitian ini penulis menemukan bahwa ekowisata (Trigonasantri Garden) dan objek wisata religius (petilasan Linggabuana) memiliki komponen fundamental-secara tradisional—relasi antara manusia, alam dan Tuhan.
\end{abstract}

Kata Kunci: pariwisata, ekowisata, wisata religius, tradisionalisme.

\section{A. PENDAHULUAN}

Abad 21 merupakan abad paradoksal. Revolusi industri 4.0 (bahkan sudah bergaung 5.0) menggiring manusia pada ruang-ruang individu yang bersifat privat (Nastiti \& 'Abdu, 2020). Ruang privat ini difasilitasi oleh perkembangan digital sedemikian rupa sehingga interaksi terjadi pada dimensi virtual. Dimensi fisik, di mana manusia sedianya melakukan interaksi fisik, mengalami pengeroposan di satu sisi. Sekalipun demikian pengeroposan ini tidak hanya menggiring manusia pada dekadensi frekuensi pertemuan fisik, melainkan memicu terjadinya krisis eksistensial (Setiawan, 2017).

Dekade pertama awal abad 21 menunjukkan krisis ini sebagai bagian yang memicu terjadinya evaluasi ulang berhubungan dengan kesadaran manusia dengan alam. Paruh kedua abad 21 terjadi pergerakan yang sangat besar dalam wilayah pariwisata. Data menunjukkan bahwa pergerakan ini sedemikian rupa sehingga asumsi dasar menengenai keterasingan dan krisisis eksistensi manusia 
sebenarnya menemukan pemecahan masalahnya dalam praktik mobilisasi fisik dalam bentuk pariwisata (Abdurrahman, 2010).

Secara sosiologis, realitas sosial terbentuk karena adanya interaksi individu-individu. Namun tentu saja tidak sekadar individu secara virtual, melainkan juga dengan individu secara riil. Persentuhan fisik membentuk persepsi-secara fenomenologis—sehubungan dengan apa itu realitas dan apa itu individu. Dalam tahap ini mulai tumbuh kesadaran bahwa betapa perjumpaan fisik demikian penting. Perluasannya tidak hanya pada perjumpaan individu secara fisik, melainkan juga persentuhan manusia (individu) dengan alam (Sena, 2020).

Sehingga jelas bahwa realitas eksternal (alam) selain merupakan sarana primer perjumpaan antara individu melainkan juga alam merupakan bagian dari yang harus ditemui oleh manusia sendiri. Hal ini karena satu-satunya dimensi di mana manusia secara eksistensial mengada adalah realitas. Manusia abad 21 memiliki caranya sendiri dalam berelasi dengan alam. Pada abad 20, sebagaimana telah dimafhum bahwa alam ditempatkan sedemikian rupa menjadi objek, telah menghasilkan katastrofi alam. Katastrofi ini berdampak panjang, tidak hanya secara mental pada diri manusia, karena katastrofi yang terjadi dipicu oleh meletupnya perang berkepanjangan, melainkan pada alam sendiri secara radikal.

Sejak akhir abad 20 isu mengenai pemanasan global, sebagai akibat dari percepatan industri dan peperangan, telah mencapai tingkat yang mengkhawatirkan. Memasuki abad 21 kerusakan ekologi terus berlanjut sebagai dampak dari pergeseran era ideologi (abad 20) ke era industrialisasi, atau era kapitalistik dan globalisasi. Implikasinya adalah jelas, meningkatnya aktivitas destruksi ekologi berupa pembabatan hutan, pencemaran laut dan hancurnya biota laut. Singaktnya alam sedemikian rupa telah dijadikan objek, dan pengobjektivikasian ini berlaku tidak hanya pada alam, melainkan juga pada manusia.

Di pertengahan abad 20, muncul apa yang disebut sebagai gerakan eksistensialis yang dipicu Humanisme sejak awal abad 20. Eksistensialisme muncul sebagai bagian dari respons dan merupakan gejala pecahnya dimensi individu dari akar sosialnya. Manusia—sebagaimana menjadi diktum Marxteralienasi dari lingkungan dan dirinya sendiri (Hendrawan, 2018; Marandika, 2018). Bahkan, secara radikal Sartre menandaskan, dalam The Closed Door bahwa: orang lain adalah neraka (Sartre, 1986). Negasi antar individu merupakan titik puncak dari terbelahnya realitas kemanusiaan secara sosial. Selain itu, sikap saling curiga, dan gelagat tendensius satu individu dengan individu lainnya menguat pada era ini. Alhasil ruang-ruang privat semakin dihargai, dan garis batas semakin tegas.

Manusia dengan manusia yang lain tampak saling memupuk kecurigaan. Terutama perasaan ini merebak pada situasi perang. Situasi perang mendesak manusia untuk mengobjektivasi subjek. Manusia adalah subjek, tapi dalam situasi perang, sebagaimana Hannah Arendt tekankan, subjek direduksi menjadi sekadar menjadi objek dan masyarakat diubah secara dingin menjadi sekadar statistik. Dalam situasi perang subjek saling mengobjektivikasi diri. Situasi genting ini secara ekosistem termasuk ke dalam situasi ambang di mana manusia sebagai puncak rantai makanan (dalam bentuk superioritas atas alam dan kerajaan hewani lainnya) saling membunuh satu sama lain (Arrendt, 1999, p. 50).

Akibat dari situasi yang bergejolak pada abad 20, tidak hanya berimplikasi pada individu, sosial maupun ekologi, melainkan juga secara radikal menggeser kesadaran manusia dari tradisi, terutama dalam hal ini agama. Situasi perang menggiring permenungan manusia pada makna Tuhan dan ekspresi beragama. Karena sebelumnya di Eropa dan Amerika (ditengarai oleh Renaisans dan menguatnya humanisme) memunculkan secara negatif pandangan positivisme, hal ini berakibat pada ditinggalkannya realitas metafisik-yang dalam banyak hal diwakili oleh Agama. Kondisi perang meradikalkan situasi batin manusia pada pengosongan batin sehubungan dengan menajamnya persoalan teodisi (Mohamad, 2011, p. 1).

Persoalan teodisi adalah persoalan abadi (perennial) mengenai bahwa jika ada Tuhan, lantas kenapa mala masih ada dan dalam hal ini tentu saja kenapa kejahatan masih ada. Jadi ini adalah 
pertanyaan eksistensial manusia-manusia beragama—dalam situasi genting hidupnya mengenai dua ujung ekstrem antara Tuhan sebagai manifestasi kebaikan mutlak dan oleh karena itu la juga adalah keadilan mutlak di hadapan situasi yang tidak baik, situasi buruk, jehat dan karenanya terasa tidak adil. Pada akhirnya manusia seakan hanya dapat memilih satu dari dua ekstrem: antara melompat pada kebaikan mutlak, atau keburukan mutlak. Seringnya, dalam situasi terjepit aspek skeptis lebih dominan daripada aspek afirmatif dalam Iman.

Fenomena kehilangan iman ini, sebagaimana digambarkan Chekhov, sebagai sesuatu yang biasa. Sebab konon orang lebih mudah kehilangan imannya daripada sapu tangannya (Chekhov, 2002, p. 1). Kepercayaan akan tradisi dan juga Tuhan mengalami kemerosotan. Dekadensi dalam aspek keimanan pada gilirannya menyumbang kerusakan ekosistem batin manusia. Alhasil untuk memenuhi kebutuhan atas kekeringan dan kerusakan batin, manusia mengembangkan banyak objek-objek pemuasan batin baru dalam bentuk yang disediakan struktur (dalam hal ini kapitalisme) maupun objek yang diciptakan sendiri.

Dilihat secara fenomenologis, hal-hal ini lebih dari sekadar kejadian acak yang bersifat kebetulan. Melainkan berakar pada tiga persoalan, manusia, alam dan tuhan. Seyyed Hossein Nasr menekankan pentingnya meninjau ulang rantai kosmologis ini. Rantai relasi yang saling berkesinambungan antara manusia dengan alam, manusia dengan dirinya dan sesamanya, dan pada akhirnya manusia dengan tuhan (Nasr, 2003a, p. 27).

Terjadinya mobilisasi dalam dimensi pariwisata pada paruh dekade pertama dan kedua abad 21 bisa dipandang sebagai salah satu upaya manusia menjalin ulang relasinya dengan alam. Sebab dia telah terasing dari akar realitasnya dan dikaburkan dengan realitas virtual. Pada saat yang sama, dari alienasi diri pada dirinya sendiri dan sesamanya, kini juga mulai ditinjau ulang betapa pentingnya berjumpa secara fisik. Bertemu wajah orang lain dan menunda segala prasangka yang sejatinya tidak pernah cocok dengan realitas yang sesungguhnya. Seiring dengan ditinjaunya ulang relasi-relasi yang terputus tadi, survei terbaru menunjukkan bahwa sekarang orang-orang kembali mulai mempertimbangkan agama sebagai bagian penting dalam kehidupan individu. Hal ini tidak sekadar terjadi di Timur melainkan di Barat. Titik balik ini menunjukkan upaya manusia mengembalikan harmoni pada realitasnya (Redfield, 2014, pp. 21, $77,85)$.

Pada level praktis, mobilisasi pada dimensi pariwisata, kiranya juga harus ditinjau ulang. Terutama jika hendak mengembalikan tiga relasi besar antara manusia, alam dan Tuhan (Nasr, 2003a, p. 49). Oleh sebab itu dibutuhkan jenis-jenis pariwisata yang sejalan dengan pembangunan ulang relasi yang telah koyak. Sebuah pariwisata yang mendekatkan manusia dengan dirinya melalui alam, sekaligus pada saat yang sama mendekatkan individu dengan kesadaran akan Yang Misteri; secara tradisional disebut sebagai dimensi religiusitas manusia yang mendalam.

Dalam konteks inilah penelitian ini akan meninjau dua model pariwisata (dari banyak model) yang ada di Darmaraja. Model ekowisata (Tanaya \& Rudiarto, 2014) dan wisata religi (Afghoni \& Busro, 2017; Hasanah, 2020) yang akan ditinjau secara interpretatif melalui perspektif tradisionalisme Seyyed Hossen Nasr (Maftukhin, 2016). Sejauh mana model-model wisata ini memberikan tidak sekadar anasir, melainkan juga wahana dan sekaligus jalan pada manusia untuk meninjau secara mendalam relasi-relasi dirinya, alam dan Tuhan yang telah sedemikian rupa mengalami dekaden. Penelitian ini bersifat deskriptif fenomenologis dengan penekanan pada interpretasi. ${ }^{1}$

\footnotetext{
1 Dalam penelitian ini fenomenologi digunakan bukan sebagai alat analisa, melankan sebagai pendekatan. Alat analisa yang digunakan di sini adalah tradisionalisme Nasr.
} 


\section{B. Hasil dan Pembahasan}

Pariwisata secara etimologis adalah kegiatan yang berhubungan dengan "perjalanan untuk berekreasi", atau pelancongan. Artinya pariwisata adalah suatu kegiatan perjalanan. Di sini, jelas ada sebuah objek. Sebab dalam sebuah perjalanan ada titik berangkat (from) dan titik tuju (to). Dengan demikian objek dan tujuan perjalanan bersifat fundamental dalam kegiatan pariwisata.

Secara lain, perjalanan dengan tujuan wisata artinya berangkat menuju sauatu tempat yang menarik untuk didatangi. Suwantoro menjelaskan bahwa objek dan daya tarik wisata adalah komponen penting untuk dapat menarik daya tarik wisata (Suwantoro, 2004, p. 56). Dengan demikian bahwa objek dan subjek saling menarik. Subjek tidak sekadar mengadakan perjalanan pada titik objek, melainkan juga objeknya juga musti merupakan objek yang memiliki daya tarik.

Secara alamiah perjalanan wisata merupakan pertemuan antara manusia sebagaimana adanya, dan sedianya juga merupakan pertemuan dengan alam (yang menjadi objek) sebagaimana adanya. Tanpa terjadinya fusi misteri ini, maka perjalanan wisata menjadi tanpa makna. Padahal sejak semula, perjalanan pada dirinya sendiri juga telah mengandung dimensi perubahan sendiri, dimensi batin yang bernilai dinamis.

Dalam gerakan Hippie yang muncul di Amerika dan Eropa pada paruh kedua adabad 20, perjalanan mengandung arti pengembangan diri dan persentuhan dengan alam secara terbuka (Coelho, 2019, p. 17). Masyarakat kota, memandang perjalanan rekreasi, yang dilakukan di akhir pekan, sebagai sebentuk pakansi yang bertujuan untuk melegakan perasaan terhimpit dari pekerjaan dan rutinitas sehari-hari. Lema praktis yang digunakan untuk kegiatan ini adalah refreshing, atau penyegaran. Dengan anasir pada kata kerja yang bersifat aktif, simultan, spontan dan oleh karena itu dinamis.

Berwisata, oleh karenanya adalah kegiatan penyegaran dari rutinitas yang monoton dan repetitif. Hal ini berlaku tidak sekadar pada aspek fisikalitas melainkan juga dengan aspek batin manusia. Sebab, dalam apa yang menjadi tradisionalisme Nasr, ditegaskan bahwa perjalanan fisik jika dilakukan sepenuh hati akan menciptakan sebuah perluasan wawasan pada subjek, dan pendalaman batin dalam pertemuan. Dalam istilah sufisme, perjalanan ini bermakna sair wa suluk, untuk menunjukkan bahwa subjek menempuh perjalanan menghampiri Yang Maha Misteri (Arts \& Sciences, 2019).

\section{Trigonasantri Garden}

Oleh karena itu selain subjek, objek menjadi penting. Di sini objek yang akan dilihat adalah ekowisata taman lebah. Sebuah taman yang merupakan wilayah pembudidayaan lebah. Objek ekowisata ini adalah Trigonasantri Garden, yang terdapat di kampung Cibarengkok, termasuk dalam desa dan kecamatan Darmaraja, Kabupaten Sumedang. Tempat yang terletak di kaki gunung Golempang dan merupakan pinggiran wilayah pengembangan wisata Jatigede, Sumedang, Jawa Barat. Taman lebah ini menempati lokasi Pusat Data dan Analisa Pondok Pesantren Al-Ma'aarij dan berdiri di atas lahan 4000-an meter persegi.

Lebah yang dibudidayakan di taman ini adalah lebah tanpa sengat (trigona) dengan sub spesies laeviceps. Pemilihan spesies ini merupakan hasil pertimbangan antara potensi pengunjung dan khasiat madu yang dihasilkan. Di atas lahan tersebut ditanami berbagai macam pepohonan (mutliflora) yang menghasilkan keteduhan di sekitar tempat budidaya dan suasana sejuk. Selain untuk kepentingan itu, pemilihan multiflora dipilih untuk hasil madu yang berkualitas. 


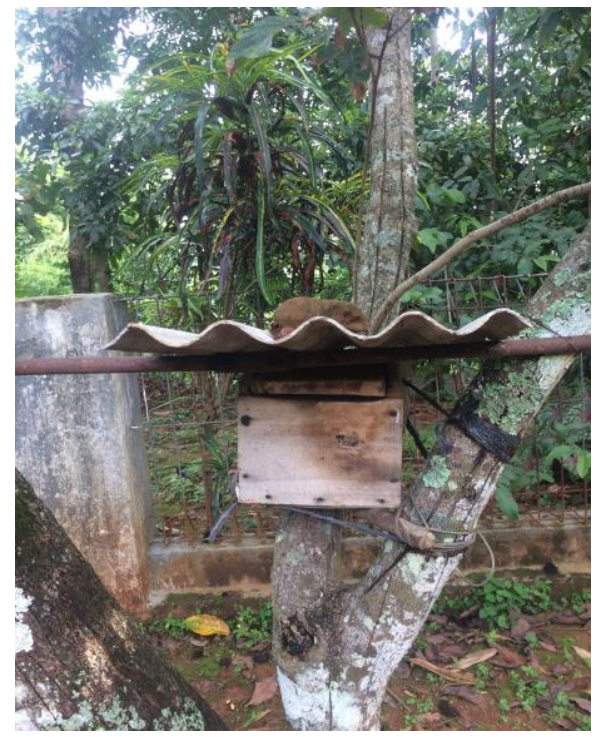

Gambar 1 Kotak Budidaya Lebah Trigona di Trigonasantri Garden

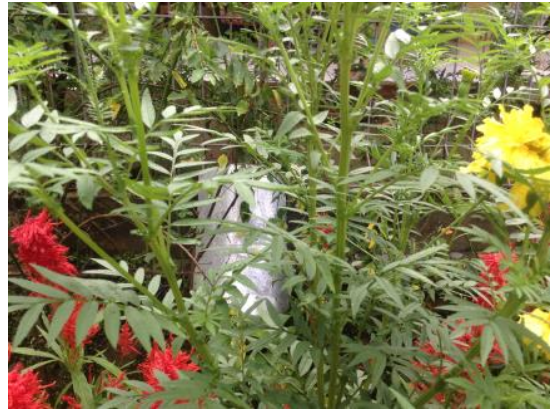

\section{Gambar 2 Multiflora Trigonasantri Garden}

Trigonasantri garden merupakan area budidaya yang terbuka untuk umum. Selain tempat budidaya, di sana juga juga merupakan pusat informasi berhubungan dengan lebah trigona. Tempat budidaya ini mendapat izin Surat Keterangan Usaha dari desa setempat sejak 2018 dan masuk ke dalam salah satu tempat budidaya dan produk agrikultur unggulan. Tempat budidaya ini terintegrasi dengan basis pesantren. Sehingga di tempat budidaya terdapat madrasah tempat mengaji dan diskusi seputar masalah aglikultur dan ekowisata.

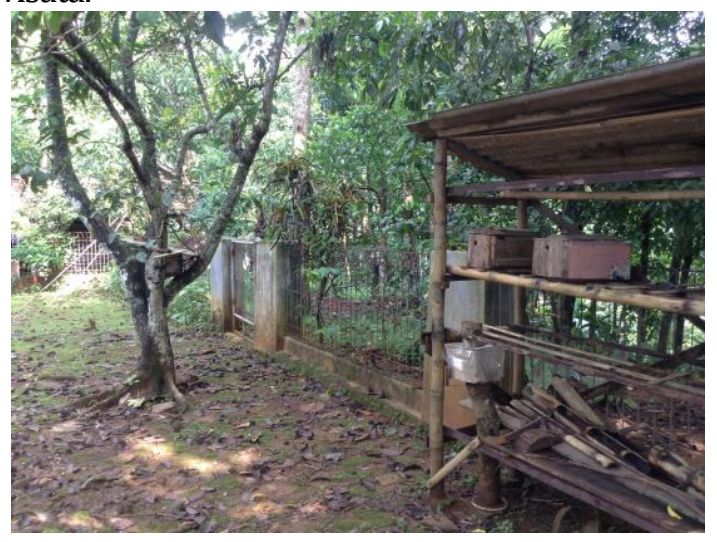

\section{Gambar 3 Rak Budidaya Lebah Trigona di Trigonasantri Garden}


Di lingkungan budidaya, selain pengunjung berkesempatan mendapat pembekalan dan informasi lengkap mengenai jenis-jenis madu dan lebah, pengunjung juga dapat mencoba panen madu sendiri dan membeli produk madu dengan kualitas terjamin. Di Trigonasantri Garden, wawasan pengunjung diperluas melalui pengalaman langsung. Mengenai bagaimana cara membedakan madu asli atau palsu, bagaimana menjaga kelestarian lingkungan flora dan mengenai falsafah berkenaan dengan lebah dan rantai ekosistemnya. Pengunjung diberi petunjuk langsung sehubungan dengan jenis-jenis lebah dan dapat mengobservasi langsung jenis spesies yang ada di sana. Proses budidaya (breeding) dan proses panen, siklus panen dan elemen-elemen fundamental mengenai komposisi madu dan khasiat yang bisa diperoleh dari madu yang dibudidayakan di sana. Selain itu, pengunjung diberikan informasi lengkap mengenai tanam-tanaman yang baik untuk lingkungan lebah dan dapat menghasilkan madu yang berkualitas. Mengenai bagaimana jenis lebah laeviceps dari rumpun trigona sangat bergantung pada tiga rantai besar ekosistem—sebagai hewan budidaya—tidak sekadar sebagai spesies yang hidup di alam secara bebas.

Pertama, lebah trigona sangat bergantung pada getah (resin). Hal ini karena untuk membuat sarang, yang kemudian diolah jadi propolis dan diinstalasikan pada sarang dan telurnya itu dibuat dari getah. Getah ini juga yang pada gilirannya akan mempengaruhi khasiat madu, sebab madu dalam lebah trigona itu disimpan di kantung yang terbuat dari propolis yang juga terbuat dari getah. Kadar propolis dalam madu trigona juga sangat tinggi (Hariyanto, 2017, p. 5) karena teknik panen pada lebah trigona (kususnya sub spesies laeviceps) itu dengan teknik pengangkatan dan pemerasan. Pengangkatan masudnya madu dan sarangnya diangkat dari sarang utama dan kemudian setelah itu diperas. Hasil perasan inilah-yang sebelumnya sudah bercampur dengan propolis dan getah mentah serta beepollen menghasilkan madu dengan kekayaan tekstur dan nutrisi.

Selain getah, yang pada gilirannya bergantung pada jenis pohon ideal apa yang harus ditanam dalam wilayah budidaya, lebah trigona juga sangat bergantung pada bunga sebagai sumber makanannya. Lebah mengumpulkan dan memakan dua hal yang dihasilkan dari bunga. Pertama, mereka mengumpulkan serbuk sari yang ada di putik bunga, untuk kemudian diproses menjadi beepollen atau beebread yang bertekstur seperti tepung dan berbau khas bunga. Pakan beepollen ini merupakan makanan utama bagi koloni lebah. Kemudian sebagai cadangan makanannya mereka sekaligus mengumpulkan nektar dari bunga—nektar adalah bagian cair sejenis embun yang dihasilkan putik bunga dan memiliki kadar glukosa. Cairan nektar ini kemudian dihisap oleh lebah, disimpan dalam lapisan abdomen lebah dan kemudian hasil dari pengumpulan dan enzim dalam tubuh lebah itulah kemudian yang menjadi bahan baku madu. Saat dikumpulkan ke dalam sarang, nektar yang telah dihisap lebah akan dikeluarkan lagi dan hasilnya inilah yang disebut madu—dan ini disimpan di dalam kantung madu khas (Putra et al., 2014).

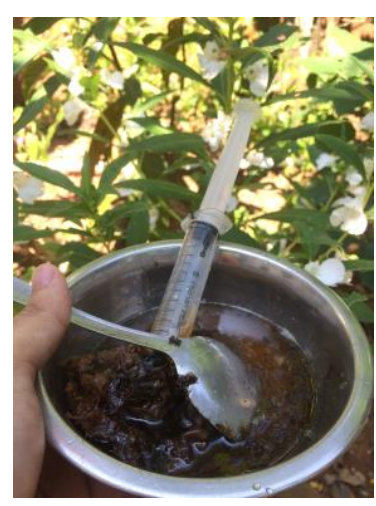

\section{Gambar 4 Cara panen madu trigona laeviceps}


Komponen ketiga yang sangat penting dalam ekosistem budidaya lebah ini adalah pendekatan pembudidaya sendiri. Pada dasarnya, jika dua komponen pertama terpenuhi lebah akan hidup sebagaimana adanya. Namun, dalam konteks budidaya, pendekatan pembudidaya sangat penting. Demikian karena pembudidaya berperan sebagai pemanen hasil dari pengumpulan cadangan makanan lebah. Tanpa observasi dan pengalaman yang memadai pembudidaya akan berpotensi merusak rantai ekologi antara lebah dan alam sendiri. Alasan yang dapat merusak ekosistem ini adalah orientasi pembudidaya yang harus dipusatkan pada pelestarian dan keberlangsungan dan bukan pada orientasi pragmatis. Titik tekan orientasi ini pulalah yang pada gilirannya menghasilkan rantai ekosistem yang baik.

Komponen-komponen pengetahuan dasar inilah yang akan didapatkan pengunjung dari ekowisata di Trigonasantri Garden. Bahwa dalam cara pemanfaatan alam sebagai titik perhatian adalah esensi dari ekowisata dan ekoturisme (Mulyana, 2019). Tanpa adanya kesadaran akan pentingnya alam melebihi tujuan lain mustahil ekowisata, atau bahkan agrowisata dapat berkembang secara alamiah dan tradisional.

\section{Petilasan Linggabuana}

Di lokasi yang sama dengan Trigonasantri Garden, juga terdapat petilasan Linggabuana. Petilasan ini adalah situs keramat yang dalam khazanah Kedarmarajaan (Kadarmarajaan) ${ }^{2}$-terutama dalam sejarah gelap (sejarah peteng) yang dasarnya adalah kelisanan — tradisional memiliki peran fundamental. Menurut sejarah lisan ini, Eyang Langlang Buana atau Ider Buana bertempat di Lingga Buana ${ }^{3}$ dan Moksha (tilem) di sana.

Situs ini adalah salah satu dari banyak petilsan di mana Eyang Langlang Buana ini secara nomadik berpindah (timbul-tenggelam). Kadangkala ia hilang dan muncul di tempat lain, dan sewaktu waktu ia kemudian muncul dan hilang lagi di petilasan ini (Bah Kamsu, juru kunci petilasan Lingga Buana, Komunikasi Personal, 13 Mei 2021). Petilasan Linggabuana oleh karenanya, meminjam nama Eyang Lingga Buana, atau Ider Buana sendiri. Nisbat ini tidak karena di sana adalah tempat Eyang Lingga Buana moksha, melainkan karena namanya yang berarti Mengelilingi Jagat. Ider Buana dalam hal ini adalah Mengelilingi Jagat dan Linggabuana bermakna Patok (untuk) Mengelilingi Jagat.

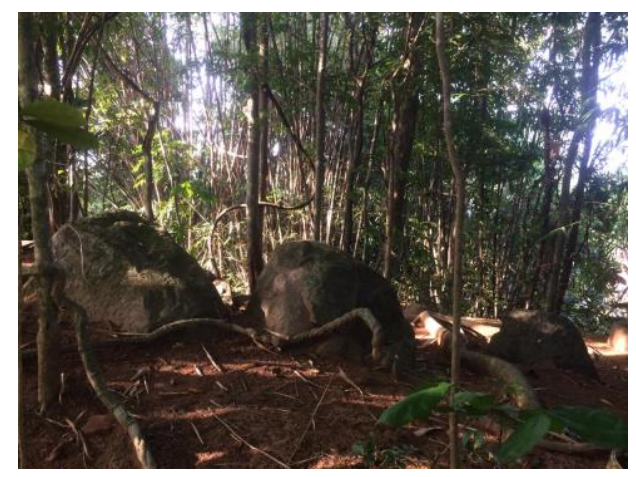

\section{Gambar 5 Gambar belakang (batu/lingga) Situs Linggabuana/Ider Buana/Langlang Buana- Cibarengkok-Darmaraja}

\footnotetext{
${ }^{2}$ Kadarmarajaan (Sunda)—adalah kata sifat untuk menunjukkan filosofi (pandangan hidup) masyarakat di wilayah Darmaraja, Kabupaten Sumedang. Kadarmarajaan memiliki struktur Kesumedangan, dengan corak pengaruh Hindu dan mistisisme lokal.

${ }^{3}$ Lingga merupakan titik pusat, sering ditandai oleh keberadaan batu monolit (tunggal) serupa obelisk dalam tradisi Mesir. Hanya saja Lingga berakar dari Hinduisme. Dalam perkembangannya kemudian, segala yang menyerupai titik pusat yang dicirikan oleh keberadaan batu juga diasosiasikan dengan Lingga, lihat gambar Situs Linggabuana.
} 
Situs petilasan Lingga Buana berada dalam wilayah Pusat Data dan Analisa Pondok Pesantren AlMa'aarij, berdampingan tepat dengan Trigonasantri Garden. Petilasan ini rutin dikunjungi oleh warga sebagai objek ziarah yang dipercayai mendatangkan keberkahan. Pada perkembangannya kemudian situs ini dikelola secara swadaya oleh masyarakat setempat. Selain itu yang menarik adalah bagaimana kemudian asimilasi tradisi lokal dengan Islam. Tampaknya keislaman yang dibangun di lingkungan pesantren Al-Ma'aarij bersifat moderat, dan secara luas mengadopsi tradisi lokal yang ada (Siti Sofiah, Komunikasi Personal, 15 Mei 2021). Alhasil pemahaman warga mengenai situs petilasan ini-alih-alih dihilangkan, sebagaimana kerap terjadi dalam perspektif Islam yang cenderung rigid-melainkan dibumikan. Fusi daripada pemahaman ini adalah terjadinya harmoni antara dimensi mistisisme Islam dan mistisisme Lokal yang secara tradisional berakar pada inti yang sama-melampaui diskusi skeptis berkenaan dengan praktik sinkretisme.

Objek petilasan ini berada di bukit terpisah dengan Trigonasantri Garden dengan kanopi yang dihasilkan dari pohon-pohon tinggi dan pohon-pohon merambat. Di area petilasan ini pengunjung biasa menghabiskan waktu merapal doa. Selain itu dalam beberapa kesempatan sejumlah santri secara rutin mengunjungi petilsan ini untuk menyerap keheningannya. Lingkungan situs secara objektif menawarkan ketenangan hutan dan impresi meditatif yang kuat.

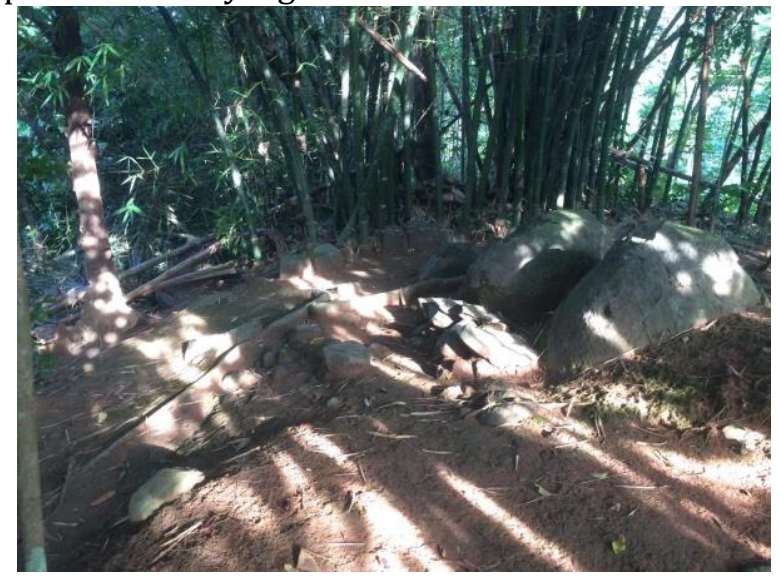

\section{Gambar 6 Gambar samping (batu/lingga) Situs Lingga Buana/Ider Buana/Langlang Buana- Cibarengkok-Darmaraja}

Dalam beberapa kesempatan, situs Lingga Buana juga digunakan sebagai tempat retret secara berjamaah. Retret ini berupa pembacaan Tawasul (Nur, 2011) dan praktik dzikir. Sebuah ritus tradisional Islam yang secara spiritual bertujuan untuk memperdalam batin dan menjernihkan pikiran. Ritus ini sangat bergantung pada tiga komponen besar. Pertama kesadaran akan dimensi Ilahiah, kedua Kesadaran akan dimensi diri, dan terakhir kesadaran akan dimensi alam.

Ritus ini diperkuat dengan proses asimilasi yang kuat. Pendiri pesantren Al-Ma'aarij, K.H. Achmad Djoenaedi Al-Banteni, berwasiat untuk dikebumikan di samping situs Lingga Buana (Siti Sofiah, Komunikasi Personal, 15 Mei 2021). Hal ini supaya terjadi kekhususan dalam ziarah para santri dan warga, dan menekan kebingungan orientasi ziarah. Bagaimanapun, karena petilasan Lingga Buana berakar pada tradisi pra-Islam, hal ini menjadi perhatian pendiri pesantren dan proses asimilasi terjadi secara bertahap.

Dalam prosesnya, ritus terus berlangsung dan baik petilasan maupun pusara pendiri pesantren menjadi pusat kegiatan spiritual warga dan santri. Tanpa adanya fusi yang bersifat fundamental ini ritus 
tradisi akan putus dengan ritus baru. Namun dalam konteks petilasan Lingga Buana tradisi lokal dan Islam berfusi dan menghasilkan harmoni.

Ditinjau secara fenomenologis, objek petilasan Lingga Buana memiliki unsur-unsur tradisi-secara wisata religius maupun secara spiritual an sich-yakni ruang dan waktu sakral. Ruang sakral bertaut dengan kehadiran alam sebagai bagian penting dari proses ritual. Bahwa alam tidak hanya dipandang sebagai aspek yang sekadar dekoratif, melainkan fundamental. Sebab alam yang asri mendukung pemusatan pikiran pada dimensi batin. Ruang pada dirinya sendiri adalah tempat tertentu. Secara fenomenologis, tempat artinya kordinat dan hal ini tidak bisa diabaikan dari rantai spritual subjek-objek. Sebab sebagaimana mesjid, dan bait Allah di Makkah, dalam tradisi Islam, ruang-ruang sakral yang disediakan di alam secara umum juga penting untuk diperhatikan sebagai komponen krusial yang mampu membangkitkan daya magis (Eliade, 2002, p. 13).

Sementara itu yang dimaksud dengan waktu sakral adalah waktu-waktu khusus yang biasa digunakan dalam ritus tradisi yang berkembang (Bah Kamsu, juru kunci petilasan Lingga Buana, Komunikasi Personal, 13 Mei 2021). Bagi para santri, ziarah di situs dan pusara Kyai pendiri pesantren dilakukan antara pagi dan menjelang petang (Siti Sofiah, Komunikasi Personal, 15 Mei 2021). Sekalipun dengan pola yang agak berbeda, faktanya adalah bahwa kunjungan antara santri dan warga ke petilasan adalah kunjungan yang bernuansa spiritual. Terlebih karena juru kunci maupun warga sekitar notabene adalah alumnus pesantren Al-Ma'aarij sendiri. Sebagai salah satu situs religi yang dikelola secara swadaya oleh masyarakat, situs Lingga Buana jelas merupakan salah satu pusat situs tradisi yang ada.

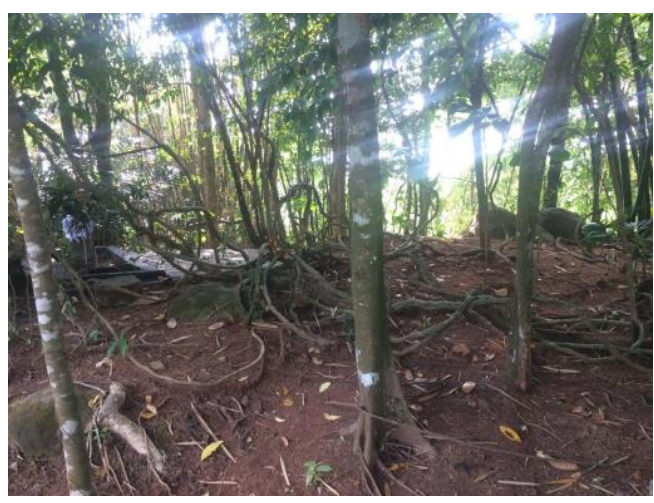

\section{Gambar 7 Gambar lanskap (batu/lingga-sisi kanan) Situs Lingga Buana/Ider Buana/Langlang Buana dan pusara K.H. Achmad Djoenaedi Al-Banteni (sisi kiri) di-Cibarengkok-Darmaraja- Sumedang.}

\section{Relasi manusia dan alam dalam ekowisata}

Dalam perspektif tradisionalisme Nasr, relasi antara manusia dan alam sedemikian rupa karena, alam alih-alih dipandang sebagai objek sebagaimana dilakukan orang dengan pandangan modern dan terjadi pada banyak kasus, melainkan dipandang sebagai sarana (Nasr, 1980, p. 5). Dalam pandangan modern, alam dilihat sebagai hambatan atau rintangan yang harus ditaklukkan, dan tidak dipertimbangkan sebagai komponen penting dalam memperkaya batin manusia. dalam tradisionalisme alam adalah sarana dan bahkan mitra sejati manusia dalam mengembangkan dimensi batinyya (Nasr, 2003b, p. 467).

Struktur kosmologi tradisional dalam padangan Nasr kiranya mengafirmasi ekowisata sebagai salah satu jalan tengah yang bisa dikembangkan untuk merajut kembali harmoni antara manusia dan alam. Sebab tidak hanya manusia yang harus dipahami sedemikian rupa, demikian juga semestinya 
dengan alam. Dengan mengenal alam manusia bisa mengenal Tuhan. Alam di sini tentu saja alam yang dimensinya sangat kompleks dan lebih dari sekadar fisik serta matematis semata (Salam, 1983, pp. 3, 6, $17,35)$.

Dalam tradisionalisme Nasr, penghargaan dan pengenalan diri manusia sangat penting dalam perjalanan spiritual. Sekaipun demikian tidak berarti bahwa hanya ada asatu jalan untuk mencapai tingkat spiritualitas tinggi. Pentingnya pemahaman akan manusia dalam konteks ekowisata tidak lantas mengesampingkan pemahaman akan alam dan dimensi-dimensi batinnya. Manusia sangat berharga sebagaimana juga dengan alam. Praktik perambahan alam, dan intervensi manusia atas alam dalam tradisionalisme Nasr sangat terbatas. Ia dibatasi oleh sifat alam sendiri, yang mana sifat alam harus dipahami betul oleh manusia. Oleh karena itu pendekatan-pendekatan manusia pada alam tidak didasarkan semata pada kepentingan manusia, melainkan terutama kepentingan alam sendiri (Nasr, 2003a, pp. 30-31).

Dalam praktik budidaya lebah dan pengelolaan Trigonasantri Garden sebagaimana dipaparkan di atas, prinsip pentingnya tidak terletak pada tujuan (manusia) menghalalkan cara (budidaya). Dengan orientasi pragmatis yang bersifat egoistis, melainkan ditekankan pada aspek kesinambungan ekologis. Pembudidaya di sini tidak bertindak semata-mata sebagai pemilik koloni lebah dan kebun/taman, melainkan terutama sebagai mitra koloni lebah dan alam sendiri. Prinsip ini sejalan dengan tradisionalisme Nasr yang menggiring manusia (yang memiliki kecenderungan bisa serakah) untuk menaruh sikap tanggung jawab. ${ }^{4}$

Sementara itu dilihat dari perspektif pariwisata murni, objek ekowisata Trigonasantri Garden memiliki sejumlah komponen dari tinjauan ODTWA Objek dan Daya Tarik Wisata Alam. Di antaranya, objek biologis di mana jelas bahwa di lokasi Trigonasantri Garden merupakan hutan produktif dengan multiflora. Selain itu, lokasi Trigonasantri Garden termasuk dalam jalur pengembangan wisata Bendungan Jatigede-Sumedang dan pengembangan objek wisata Gunung Golempang, yang masih dikembangkan oleh pemerintah desa Darmaraja Kabupaten Sumedang. Bahkan bisa dikatakan Trigonasantri Garden sebagai potensi ekowisata telah lebih awal dirintis sejak 2017 akhir dari pengembangan wisata lain di wilayah Bendungan (Nursya'aadah, Sekretaris Bidang Pemasaran produk Trigonasantri, Komunikasi Personal, 20 Mei 2021).

Dari sisi fasilitas Trigonasantri Garden memiliki satu wc umum dengan kapasitas memadai dan akses air bersih dari sumber mata air terdekat. Sementara akses jalan adalah jalan desa (desa Darmaraja) yang berjarak 500an meter dari pusat kota Kcematan (alun-alun) darmaraja. Aksesnya memang perlu mendapat perhatian khsus dari pemerintah mengingat jalan yang sama juga digunakan untuk aktivitas produktif warga atas hutan produktif. Sebagai objek ekowisata, Trigonasantri Garden merupakan salah satu alternatif dari banyak pilihan wisata yang ada. Terutama atas pertimbangan kepresisiannya dalam dimensi tradisi.

\section{Relasi manusia dan Tuhan dalam wisata religius}

Situs Linggabuana sebagai objek wisata religi, membangun relasi berkesinambungan antara manusia, alam dan Tuhan. Dalam perspektif Nasr, karena alam adalah mitra manusia dalam menempuh dan mencapai batinnya sendiri, pada saat yang sama, ikatan individu dengan Tuhan juga akan terjalin (Nasr, 2003a, p. 49). Selain itu, secara fenomenologis rantai sakralitas, ruang-waktu dan ritus sakral membentuk pola yang berkait-kelindan dengan para pengunjung yang datang ke situs tersebut. Ini karena

\footnotetext{
${ }^{4}$ Lihat ceramah Seyyed Hossen Nasr bertajuk, Islam and the Preservation of the Natural Environment, di kanal Youtube, yang menekankan sikap tanggung jawab manusia di hadapan alam yang pada gilirannya menentukan hasil dan kedalaman batin manusia sendiri secara spiritual.
} 
dalam apa yang menjadi prinsip sakralitas disebut dengan simbiosis eksoteris-esoterisme di mana Nasr mengembangkannya dari Frithjof Schuon (Schuon, 2000, p. 25).

Simbiosis ini terjadi terutama dalam ritus yang dilakukan di petilasan Linggabuana. Di mana eksoterisme; manusia juga dipandang sebagai agen dan bagian dari realitas eksternal, juga alam sebagai objek sekaligus subjek yang menentukan kedalaman batin dan situasi yang dihasilkan oleh alam mengantarkan manusia pada level meditasi batin tertentu, dan pada gilirannya sampai pada dimensi esoterisme. Simbiosis ini tidak terjadi seandainya satu di antara rantai-rantai manifestasi dan ritus di petilasan Linggabuana tidak terjadi dan tidak terjalin.

Saat proses simbiosis tidak terjadi, misalnya demi kepentingan pragmatis objek ini dipugar dan tidak mengindahkan prinsip-prinsi tradisi dan keasrian alam, maka putuslah ritus dengan sumber dan akar tradisinya. Tradisi di sini tidak dipandang sebagai laku manusia di hadapan alam melainkan laku manusia di hadapan semesta secara keseluruhan. Tradisi oleh karena itu bukan sesuatu yang bersifat antoposentris semata melainkan juga sekaligus teosentris. Aspek ketuhanan dalam tradisi terkandung dalam nilanya atas yang sakral dan Yang Riil. ${ }^{5}$ Situs Linggabuana memuat komponen tradisi dengan simbiosis ekso-esoteris yang berkesinambungan antara manusia, alam dan Tuhan.

\section{SIMPULAN}

Ekowisata Trigonasantri dan situs Linggabuana dengan jelas dapat dilihat dalam dua sisi. Pertama sebagai objek wisata (ekowisata) dan objek wisata religius. Kedua sebagai objek wisata secara pragmatatis. Dalam sudut pandang pertama, kedua objek wisata tersebut telah memenuhi kriteria minimum sebagai objek wisata, baik dari segi akses, objek dan fasilitas.

Sementara itu dari sisi kedua ekowisata Trigonasantri Garden dan situs petilasan Linggabuana dalam hubungannya dengan relasi manusia, alam dan Tuhan terjalin dalam semua aspek. Relasi antara manusia dengan dirinya sendiri terjadi dalam perjalanan wisata sendiri. Kemudian jalinan antara manusia dan alam terjadi baik dalam proses edukasi di Trigonasantri Garden maupun dalam persentuhan dengan dalam di situs petilasan Linggabuana yang mana keduanya menekankan pentingnya alam dan pentingnya menyadari keberadaan alam sebagai mitra perjalanan manusia pada Yang Riil dan Yang Sakral, yakni Tuhan. Komponen ketiga, relasi manusia dengan Tuhan terjadi saat manusia dapat merasakan tarikan meditasi alam, termasuk melalui pendalaman pendalaman pemahaman manusia (individu) pada sifat dan karakter alam.

Simbiosis baik secara pragmatis dalam bentuk wisata, maupun secara biologis dengan alam, dan juga dengan Tuhan, terjadi secara simultan dan saling mengisi di objek ekowisata Trigonasantri Garden dan objek wisata religius situs petilasan Linggabuana. Pendekatan tradisionalisme Nasr mengafirmasi keduanya sejauh rantai simbiosis ekso-esoterisme terjaga dan berakar pada Yang Riil dan Tuhan sendiri. Tanpa akar yang kuat atas Yang Riil, sebagai manifestasi Tuhan dalam realitas eksternal, modus-modus yang lain hanya akan berbuah ekses negatif baik pada manusia, dan terutama dalam hal ini pada alam juga dan alhasil putusnya relasi sakralitas manusia dengan Tuhan.

\footnotetext{
5 Dalam Islam, Yang Riil, melalui perspektif sufisme dipandang sebagai Al-Haqq “The Truth" atau "Sang Kebenaran", yang mencakup tidak hanya Tuhan sendiri melainkan juga seluruh manifestasinya secara eksternal. Sehingga saat orang menyebut Yang Riil, artinya dia sedang menyebut selurus realitas mikro-makrokosmis atas dimensi Tuhan. Baik sebagai Dia yang Intim, atau Dia yang Memanifestasi. Lihat, Frithjof Schuon, Prosesi Ritual Menyingkap Tabir Mencari Yang Inti, h. 151
} 


\section{Daftar Referensi}

Abdurrahman, A. (2010). Tourism Industry; Rekam Jejak Peristiwa Dan Perubahan Budaya. KARSA: Journal of Social and Islamic Culture, 18(2), 85-95.

Afghoni, A., \& Busro, B. (2017). Potensi Wisata Tradisi Syawalan di Makam Gunung Jati Cirebon. Jurnal Kepariwisataan: Destinasi, Hospitalitas Dan Perjalanan, 1(2), 72-82. https://doi.org/10.34013/jk.v1i2.12

Arrendt, H. (1999). Asal-usul Totalitarianisme. Yayasan Obor Indonesia.

Arts \& Sciences. (2019). COLL 300: Muhammad Baqir: 'Movement/Migration'. Arts \& Sciences W\&M. https://www.youtube.com/watch?v=iffOsXtHk5U

Chekhov, A. (2002). Pengakuan: Sekumpulan Cerita Pendek. Gramedia.

Coelho, P. (2019). Hippie. Gramedia.

Eliade, M. (2002). Sakral dan Profan. Fajar Pustaka.

Hariyanto, R. A. B. (2017). Penentuan Kandungan Fenolik, Flavonoid dan Aktivitas Antioksidan dari Ekstrak Propolis Trigona sp. Institut Teknologi Sepuluh Nopember.

Hasanah, N. (2020). Analisis Keberadaan Wisata Religi Terhadap Peningkatan Kesejahteraan Masyarakat Pelaku Usaha. Jurnal Qiema (Qomaruddin Islamic Economics Magazine), 6(2), 164-190.

Hendrawan, D. (2018). Alienasi Pekerja Pada Masyarakat Kapitalis Menurut Karl Marx. Arete, 6(1), 13-33.

Maftukhin, M. (2016). Teologi Lingkungan Perspektif Seyyed Hossein Nasr. Dinamika Penelitian: Media Komunikasi Penelitian Sosial Keagamaan, 16(2), 337-352.

Marandika, D. F. (2018). Keterasingan Manusia menurut Karl Marx. TSAQAFAH, 14(2), 229-322.

Mohamad, G. (2011). Debu, Duka, Dsb: Sebuah Pertimbangan Anti-Theodise. Pusat Data dan Analisa Tempo.

Mulyana, E. (2019). Upaya pemberdayaan ekonomi, sosial dan budaya pada masyarakat melalui pengembangan bisnis ekowisata. Business Innovation and Entrepreneurship Journal, 1(1), $38-43$.

Nasr, S. H. (1980). Islam dalam Cita dan Fakta. LEPPENAS.

Nasr, S. H. (2003a). Antara Tuhan, Manusia dan Alam. IRCiSod.

Nasr, S. H. (2003b). Ensiklopedi Tematis Spiritualitas Islam: Fondasi. Mizan.

Nastiti, F. E., \& 'Abdu, A. R. N. (2020). Kesiapan Pendidikan Indonesia Menghadapi era society 5.0. Jurnal Kajian Teknologi Pendidikan, 5(1), 61-66.

Nur, F. M. (2011). Konsep Tawassul dalam Islam. Substantia: Jurnal Ilmu-Ilmu Ushuluddin, 13(2), 267-273.

Putra, P. A. H., Watiniasih, N. L., \& Suartini, N. M. (2014). Struktur dan Produksi Lebah Trigona spp. pada Sarang Berbentuk Tabung dan Bola. Jurnal Biologi, 18(2), 60-64.

Redfield, J. (2014). Visi Celestine. Gramedia.

Salam, A. (1983). Sains dan Dunia Islam. Pustaka.

Sartre, J. P. (1986). Pintu tertutup. Pustaka Jaya.

Schuon, F. (2000). Prosesi Ritual Menyingkap Tabir Mencari Yang Inti. Srigunting.

Sena, I. G. M. W. (2020). Relasi Manusia, Alam dan Tuhan Dalam Harmonisasi Semesta. Sphatika: Jurnal Teologi, 9(1), 15-21.

Setiawan, W. (2017). Era Digital dan Tantangannya. Seminar Nasional Pendidikan, 1-9.

Suwantoro, G. (2004). Dasar-dasar Pariwisata. Andi Offset.

Tanaya, D. R., \& Rudiarto, I. (2014). Potensi pengembangan ekowisata berbasis masyarakat di kawasan Rawa Pening, Kabupaten Semarang. Teknik PWK (Perencanaan Wilayah Kota), 3(1), 71-81. 